\title{
Science Teaching and Level of the Scientific Literacy of the Primary School Teacher in Jordan
}

\author{
Tahani Alebous \\ The World Islamic Sciences and Education University, Jordan
}

\begin{abstract}
The study aimed to cerebrate and reflect on the status of teaching science in the first three primary grades in Jordan. After the application of developed curriculum, and to find out whether there is a relationship between gender and levels of scientific literacy.

The study population consisted of all science teachers, whom working in Amman education directorate. Based on new national curriculum, and substantial new data which collected from interviewing teachers among many science teachers feel overloaded with teaching science, so there is gap between ideal and actual picture. Performance of teaching science resulted from the limited content of accumulated knowledge, and low scientific literacy level. Parents play a very weak role in improving teaching science.

The recommendations developed to improve the status of science education, in order to reach optimal status through all the elements that effecting the education cycle, teachers, supervisors and parents.
\end{abstract}

\section{Introduction}

The primary education as we know is critical and important stage for students' educational life, because it is the main base for the next coming stages of education it had been underlined clearly in the Universal Declaration on Education for All conference was held in Thailand in 1990 the recommendations of this conference were the most important provision of basic education for all, and improve the quality of education [19]. The philosophy of the education in Jordan based on the basis of ideological spiritual, intellectual, social, cognitive, and confirms the interest of government basic education in Jordan Article 9 of the Education Act No. 3 of 1999 states the following " Elementary Education is the main base for education and the basis for a remote national unity and national capacity development and self-orientation and guidance of students [13].

The results of the analytical study of TIMSS in 1999 indicated that the low level of students at the basic science resulted from the traditional teaching methods. Thus, the Ministry of Education has to reconsider the current curricula and attach more attention to learners and the teaching methods being followed in the class.

In 2002 royal directives were issued on the future of Jordan, highlighting the importance of a new educational trend titled "knowledge- based economy".

Education is an effective tool to prepare and enable the community members to meet the challenges and explore world cultures and from this point there is a real need to build new approaches and focus on the student and a curriculum to include and maintain new strategies in line with the efficiencies of knowledge-based economy system [13].

The activities of science teachers based on cognitive abilities and perceptions and trends toward science teaching and learning strategies followed by the climate and environment in which teaching and students provided in sharing of science and through their behavior in general education [9].

Jordan is the one of the countries that started to overview the educational system, aiming at all its inputs, processes, and outputs through a scientific and practical framework. Science is one of the most important subjects in primary school education.

So this study aims to shed light on the role of the teacher for the first three grades in the process of learning science, the level of their scientific literacy, and the impact of the knowledge economy on Science Education in Jordan.

\section{Importance of the study}

The importance of this study comes from the role that the primary science education will integrated with other subjects. It seems to be important to determine the literacy level of primary teachers, who are teaching science and technology courses terms of improving the quality of science education.

This study will be also explore reality of science education for basic grades, and the level of scientific literacy, by attempting to detect the difficulties to diagnose reality and take advantage of the results in educational development, especially at the current stage of Arab revolution spring we need to focus more on creating scientific thinking. 


\section{Problem of the study}

The researcher noticed a lack and scarcity of research which concerned about the reality of teaching science and the level of scientific literacy of the first three grades teachers in spite of the importance of this stage where the basic construction of accumulated knowledge for the student regarding sciences and languages.

\section{Questions of the study}

1. What is the status of Science teaching and learning in the first three primary grades in Jordan?

a. How is science teacher planning for teaching science?

b. What is the teaching strategy science teacher applying?

c. What is the evaluation strategy science teacher applying?

d. What is the role of the supervisor to help and enable science teacher?

e. What is the role of parents to help their children in learning science?

2. What is the level of scientific literacy of primary three grades teachers?

3 . Is there a relationship between gender and levels of scientific literacy?

\section{Methodology of the study}

In order to achieve the study objectives and to answer the questions of the study, the researcher will conduct interviews and design a questionnaire, as well as document analysis. The following paragraphs describe data collection process.

\subsection{Population of the study and its sample}

The study population and its sample consist of all the science teachers, parents (males, females), for the three primary grades and they were (550) teachers, and (5) supervisors. The study sample comprised (52) teachers, and (30) parents, who were randomly selected from the schools of Amman education directorate for the First Region. And (5) supervisors represents the whole population, in 2011-2012 scholastic year.

\subsection{Data collection instrument}

The researcher had interviewed the science teachers and supervisors, parents, in order to gather active data and to know responses from the teachers, supervisors and parents.
The three interview instrument and the questionnaire consist of questions prepared depending on literature review about knowledge economy and science education for primary grades In order to verify the authenticity of the instruments, the researcher had given them to twelve specialists in the field of science education and curricula and teaching methods.

They were asked for their views regarding the questions of the instrument in terms of representation of knowledge-based economy and science education standards and criteria as well as the clarity of the questions and the accuracy of linguistic formulation. The proportion of the agreement adopted was (87\%) in order to adopt the questions or delete them, thus, the researcher came up with the following interview instruments:

a) Teachers interview consists of (23) questions).

b) Supervisor interview instrument consists of (13) questions.

c) Parents interview instrument consists of (10) questions. And the questionnaire of scientific literacy of the first three primary grades teachers consist of 27 questions of "knowing and internalizing" requiring to choose one response out of three which are "true", "false" and "I do not know".

\subsection{The study plan}

After the preparation of study tools and judged by a jurisdiction, the researcher visited the Directorate of Education of Amman (1) to get the raw data of the number of schools affiliated to the ranks of the first three, amounting to 71 schools, 12 males and 59 females, (550) teachers (62) males 488 females. After selecting the schools that all male schools were selected, amounting to (12) male schools, and (40) female schools were selected randomly and therefore females chosen at random from the (52) teachers of these schools to meet them. And then, the researcher visited the schools and submitted the application of specific tools interview as follows:

- A tool for interview the teacher: questions were directed to the science teacher was discharged paper Supervisor interview tool: After interview teachers, supervisors were interviewed. Parent's interview tool: After interview supervisors, parents were interviewed.

- Questionnaire of scientific literacy: it was distributed after interview primary teachers.

\section{Literature Review}

Research indicates that, a number of primary school teachers avoid teaching science, are not knowledgeable about science, and lack confidence to teach it [12], [14]. 
The teacher is the backbone of the educational process and the worker and the President Responsible for the success or failure of the teaching - learning process. Governance on the efficiency of the teacher focused on the two forces equal: knowledge of the scientific lessons that is taught and in carrying out his cart and his ability to express the realities of the lessons [21].

The literature indicates that educational projects focus on the preparation of teachers such as the 2061 and some studies suggest that there is a problem in the preparation of teachers, especially science teacher's stage of the basic [7]. This study aimed to answer the question: How will the science class will be in 2005? And how the teacher will help students to possess the skills and abilities to answer questions and challenges they will face in the century atheist and twenty-reaching: The textbook will be a reference and will not be the main source of knowledge and the evaluation process continues. Tsai conducted a study to identify the teachers' beliefs, and convictions about the nature of material science, and methods of learning which they depend, through the interview 27 Science teacher Taiwan, were classified into three types: traditional, structural, progressive [18]. Most of them were traditional science teachers. The study indicated that, that half of science teachers belong to the school of knowledge and influence the way of teaching.

Fan and Chen [10] examined multiple measures of parent involvement. Using the methodology of meta-analysis (analyzing multiple research studies), the researchers identified three constructs of parent involvement: (1) communication, (2) supervision, and (3) parental expectations and parenting style.

Ahmet and Murat [2] conducted a study to investigate the level of the scientific literacy of primary school teacher candidates; the sample consists of ninety females and forty-two male primary teachers. They found that males are not more significantly scientific literate than females, and that teacher candidates the lowest success rate (39.70) on the items of science and technology.

Chin [6] conducted a study to investigate whether first-year pre-service teachers in colleges in Taiwan have a satisfactory level of scientific literacy; the instruments used were Chinese translations of the Test of Basic Scientific Literacy (TBSL) and the Test of Science-related Attitudes. The statistical results from the tests revealed that, in general, the basic scientific literacy of first-year pre-service teachers was at a satisfactory level.

\section{Results of the study}

What is the status of Science teaching and learning in the first three primary grades in Jordan? The results of teacher interview members of the study sample showed that $59 \%$ of the interviewed teachers have bachelor degrees and $41 \%$ have a diploma.

\subsection{Teacher plan for lessons}

After reviewing the plans the researcher found that:

- The general shape of the plan, most of the plans were unconvincing because they don't contain the name of the school year, not arranging the margins, write phrases inappropriately keeping plans in a way that is appropriate for places.

- Most of the teachers (74\%) did not change the way they prepare for the curriculum that appear in the knowledge economy only in the outline.

\subsection{Daily plans}

The results of data analysis showed the following:

- The percentage of goals in the daily preparation of teachers as in the following Table 2.

Table 2. Percentage of Goals

\begin{tabular}{|c|c|c|c|}
\hline Grade & $\begin{array}{c}\text { cognitive } \\
\text { goals } \%\end{array}$ & $\begin{array}{c}\text { skill } \\
\text { goals } \%\end{array}$ & $\begin{array}{c}\text { emotional } \\
\text { goals \% }\end{array}$ \\
\hline First & 70 & 19 & 11 \\
\hline Second & 80 & 15 & 5 \\
\hline Third & 77 & 23 & 0 \\
\hline
\end{tabular}

What is the teaching strategy science teacher use?

- Most of science teachers for grades first three (most of them use the method of explanation and only $9 \%$ use the practical experimentation. Most of the teachers are not used to follow daily plan during lessons.

\subsection{What is the evaluation strategy science teachers apply?}

- Most of teachers try to use evaluation strategy of knowledge economy.

- Most of teachers evaluate students at the end of unit to label them.

\subsection{What is the role of supervisor to help science teacher?}

- None of supervisors are specialists in science.

- Most supervisors verified the weakness of teachers in the preparation of daily plans.

- Teachers have been trained by the supervisors on the preparation of plans, but teachers need to be followed up more than on time. Most supervisors could not visit science teachers more than once during the semester. 


\subsection{What is the role of parents to help their children?}

- None of parents have knowledge about outcomes of science.

- $23 \%$ of parents have knowledge about Educational Reform of Knowledge Economy.

- None of parents are trained on how to deal with new science textbooks.

- $79 \%$ of parents see their roles in science, only as ensuring that tasks taken at schools like homework.

- $32 \%$ of parents accepted that there is informal science learning in museums, science centers and science trips.

\subsection{What is the level of scientific literacy of primary three grades teachers?}

At the end of the study, it was found that the level of scientific literacy is low; they are not willing to follow technological and scientific developments. The mean and Std. Deviation of statements in the scientific literacy questionnaire are outlined in the Table 3.

Table 3. Mean and Std. Deviation of scientific literacy questionnaire

\begin{tabular}{|c|c|c|}
\hline Statement & Mean & Std. deviation \\
\hline $\begin{array}{l}\text { The use of inquiry requires the } \\
\text { belief that the mind of the } \\
\text { student information }\end{array}$ & 1.25 & 0.54 \\
\hline $\begin{array}{l}\text { Scientific inquiry attributes } \\
\text { construct meaning from data } \\
\text { and observations. }\end{array}$ & 1.16 & 41 \\
\hline $\begin{array}{l}\text { All scientific inquiry include } \\
\text { scientific experimentation }\end{array}$ & 1.55 & 0.62 \\
\hline $\begin{array}{l}\text { A safe classroom environment } \\
\text { must provide for students to } \\
\text { practice inquiry. }\end{array}$ & 1.13 & 0.43 \\
\hline $\begin{array}{l}\text { Science can predict events may } \\
\text { get after several years }\end{array}$ & 1.43 & 0.67 \\
\hline $\begin{array}{l}\text { Science aims to describe } \\
\text { natural phenomena }\end{array}$ & 2.03 & 0.60 \\
\hline $\begin{array}{l}\text { Anyone can exercise science, } \\
\text { regardless of race, cultures, } \\
\text { religion. }\end{array}$ & 1.28 & 0.52 \\
\hline $\begin{array}{l}\text { Scientific theories developed } \\
\text { with time and scientific } \\
\text { instruments used. }\end{array}$ & 1.06 & 0.25 \\
\hline $\begin{array}{l}\text { Scientific facts relatively } \\
\text { constant }\end{array}$ & 1.51 & 0.65 \\
\hline $\begin{array}{l}\text { The scientists change/ modify } \\
\text { the results according to the } \\
\text { basis of their convictions and } \\
\text { personal feelings }\end{array}$ & 1.83 & 0.45 \\
\hline $\begin{array}{l}\text { Scientific concepts depend on } \\
\text { scientific facts. }\end{array}$ & 1.23 & 0.53 \\
\hline $\begin{array}{l}\text { Several scientific findings } \\
\text { weaken science. }\end{array}$ & 1.23 & 0.61 \\
\hline $\begin{array}{l}\text { Good scientist accepts results } \\
\text { and the opinions of others. }\end{array}$ & 1.71 & 0.46 \\
\hline $\begin{array}{l}\text { Values and customs affect the } \\
\text { technological development }\end{array}$ & 1.86 & 0.51 \\
\hline
\end{tabular}

\begin{tabular}{|l|c|c|}
\hline community & & 0.40 \\
\hline $\begin{array}{l}\text { Educational policies guide a } \\
\text { search path of scientific and } \\
\text { technological development }\end{array}$ & 1.26 & 0.48 \\
\hline $\begin{array}{l}\text { Technology serving and guide } \\
\text { research and experiments } \\
\text { scientists }\end{array}$ & 1.15 & 0.55 \\
\hline $\begin{array}{l}\text { Technological development } \\
\text { could lead to environmental } \\
\text { problems }\end{array}$ & 1.20 & 0.67 \\
\hline $\begin{array}{l}\text { Scientist can change scientific } \\
\text { findings to serve his /her } \\
\text { personal interests }\end{array}$ & 1.28 & 0.40 \\
\hline $\begin{array}{l}\text { Researcher faith in God and the } \\
\text { unseen, incompatible with } \\
\text { science }\end{array}$ & 1.81 & 0.72 \\
\hline $\begin{array}{l}\text { chemical reactions occur } \\
\text { everywhere in nature }\end{array}$ & 1.51 & 0.48 \\
\hline $\begin{array}{l}\text { Minerals good conductor of } \\
\text { heat }\end{array}$ & 1.21 & 0.84 \\
\hline $\begin{array}{l}\text { The element of carbon has } \\
\text { isotopes }\end{array}$ & 1.70 & 0.85 \\
\hline $\begin{array}{l}\text { Can estimate the age of the sun } \\
\text { around billions of years }\end{array}$ & 1.51 & 0.94 \\
\hline $\begin{array}{l}\text { Combustion of gasoline lead to } \\
\text { acid rain }\end{array}$ & 2.01 & 0.72 \\
\hline Insect are abundant organisms & 1.41 & 0.56 \\
\hline $\begin{array}{l}\text { Scientists use one way to take } \\
\text { actions scientific research } \\
\text { ssientific method }\end{array}$ & 1.81 & 06 \\
\hline $\begin{array}{l}\text { A scientific fact does not } \\
\text { produce the scientific principles } \\
\text { and theories. }\end{array}$ & 1.91 & \\
\hline Total & 39.48 & \\
\hline
\end{tabular}

The table showed that the mean was low for the most statements except statement number 6.24 which related to nature of science.

Table 4. Mean and Std. Deviation of gender

\begin{tabular}{|l|l|l|}
\hline Gender & Mean & Std. Deviation \\
\hline Female & 38.92 & 4.27 \\
\hline Male & 39.63 & 3.30 \\
\hline
\end{tabular}

Furthermore, simple statistical procedures were used to assess the significance of differences between genders within the sample (independent samples t-test). Independent t-tests were conducted at the 0.05 level of significance for all data.

\subsection{Is there a relationship between gender and levels of scientific literacy?}

Table 5 indicated the significant gender-related difference in scores on questions of scientific literacy questionnaire items; although the mean score of males (39.63) was higher than females (38.92), the difference is not meaningful 
Table 5. Distribution of gender-related t-test scores on scientific literacy questions

\begin{tabular}{|c|c|c|c|c|c|}
\hline \multirow[b]{2}{*}{ Df } & \multirow[b]{2}{*}{$\mathrm{T}$} & \multicolumn{2}{|c|}{$\begin{array}{l}\text { Levene's Test for } \\
\text { Equality of Variances }\end{array}$} & & \\
\hline & & Sig. & $\mathrm{F}$ & & \\
\hline $\begin{array}{l}\text { Up } \\
\text { per }\end{array}$ & \begin{tabular}{|c|}
$L$ \\
$o$ \\
$w$ \\
$e$ \\
$r$ \\
\end{tabular} & Upper & Lower & & \\
\hline 58 & $\begin{array}{l}5 \\
5 \\
8\end{array}$ & .160 & 2.027 & $\begin{array}{l}\text { Equal } \\
\text { variances } \\
\text { assumed }\end{array}$ & Total \\
\hline $\begin{array}{l}24 . \\
30 \\
5\end{array}$ & $\begin{array}{l}6 \\
4 \\
6 \\
\end{array}$ & & & $\begin{array}{l}\text { Equal } \\
\text { variances not } \\
\text { assumed }\end{array}$ & \\
\hline
\end{tabular}

\section{Discussion}

This study has clarified that the teachers don't like to teach science for primary classes because they found that the textbooks are too long to cover through school year, and they don't have enough time to cover other materials such as ; mathematics, Arabic language, religion, sometimes they use science class for teaching Arabic language, ... etc., also the Teachers who have low scientific literacy level cannot be expected to grow scientifically literate students or to apply the developed curriculum effectively.

\subsection{Qualifications of the first three grades teachers}

- Most classroom teachers of the first three grades, low rates in high school (Tawjhi) and forced to study "Class Teacher, and Fosterling" in bachelor.

- Most of them are not willing to specialize and thus they are not qualified to teach science, and this is consistent with the study of [11] found in his study that $28 \%$ of science teachers were qualified to teach Science for elementary classes . So that the generalist teachers teaching science, given the ongoing evidence of teachers' difficulties with primary science. This is consistent with a study of [3] which confirmed that preparation programs in the universities, before the service is not suitable for the preparation of future teachers. The researcher thinks that the education system for university should be aware of primary teacher programs, the researcher think the students in these programs should be the excellent one in their high school (Tawjhi) these programs in the university should take the students whose rate at least $80 \%$. An alternative suggestion the researcher agrees with it, made by others is to have specialist science teachers in the primary school [1].

\subsection{Planning}

Most of the results showed that the vast majority of teachers' plans are not carried out effectively in the classroom, focused on the goals of knowledge neglecting other important educational including the individual differences among students. This is consistent with studies of Anthony [4]; Lena [11]. This could be attributed to the lack of training workshops and communication between the teachers and supervisors.

\subsection{Teaching science in classroom}

Results showed that teachers meet only $17 \%$ turn to use strategies such as knowledge-based economy, to stimulate students and make it the center of the educational process and take into account individual differences in explaining the lesson and use of educational technology in the commentary, and the laboratory. And this agrees with Symington and Hayes, who noted how preserves teachers avoided acquiring the necessary science background knowledge when preparing science lessons [17]. When teachers lack confidence to teach science, they tend to use teaching strategies which allow them to maintain control of the classroom knowledge flow.

The study showed that most teachers still use traditional methods due to the following effecting elements:

1. Three classes per week for science lesson.

2. Length of the threads in the book of science and sometimes repeated. This is consistent with the study of Stefanich and Kelsey [15] which indicated that time spent in science education less than any other study material. Yager and Lutz noted that most students spend listening in science class to explain and to read from the textbook and the conservation and frequency of the scientific facts [20]. As Appleton [5] refers that teacher education programs have also received criticism (e.g., DEET [8]) for not preparing teachers adequately. Although educational development towards the knowledge economy in Jordan take place ten years ago, but we still need time to change and to be more practical without depending fully on theory.

\subsection{Evaluation}

Most of the teachers use evaluation to label their students; most of the questions come to the remembering and neglecting higher-order thinking skills. $40 \%$ of teachers do not use evaluation strategies based on the new Knowledge Economy effectively. Also parent's opinion plays a role here in evaluation, because they get used to have marks and 
that evaluation they need for their kids. The researcher believes that there is a gap between theory and practice in evaluative strategies which reflect education of knowledge economy.

\subsection{Educational supervisors}

The study results showed that all the supervisors of the first three grades are not specialist in science; the researcher believes that most of teachers and supervisors have some shortcomings, or that they are recalcitrant or resistant to change! Although the Ministry of Education applies education depending on knowledge economy, we still need more and more focus on science on practice rather than theory.

\subsection{Parents}

The study result showed that most of parents are not trained or have a knowledge about " ERfKE", or science outcome, and that most of them prefer to have marks for their children, they don't worry about skills, although" ERfKE" strategy is based on structuring the educational system to ensure lifelong learning. Most of parents see their roles only by following up home works of science; this is consistent with studies of Fan and Chen [10]. Also the results clarified that there is a gap between parents and teachers and this gap should be linked to improve learning science, developing student's skills in science. The researcher strongly believes that parents can improve their children's knowledge of science, by playing many effective roles at schools to enhance and improve learning science. And this can be achieved by developing strategy, for parent professional development, but we still need high quality initiatives to improve science teaching.

\subsection{Scientific Literacy}

The study result showed that most of primary teachers at least minimally knowledgeable about the science subjects and phenomena, and nature of scientific, and they do not actively follow the developments in the field of science and technology. Based on these findings, with regards to the dimensions of scientific literacy considered here, it seems to be possible to claim that the primary teachers do not have enough level of scientific literacy; this is in line with results [2].

\section{Conclusion}

Education in Jordan in general and primary science education in particular enjoyed a great and perpetual concern after recognizing of the importance of education and its role in developing Jordanian the society in various fields. Despite the achievements in providing primary education, the gap between the real and actual status of teaching science still needs more and more efforts. Many primary school teachers do not reflect their new role toward Educational Reform for Knowledge Economy "ERfKE", they only used teacher discussions, teacher explanation and teacher demonstrations strategy. This refers to the need for more integration with the role of supervisors and parents to help and improve science learning for primary three grades. Although the Education Reform for Knowledge Economy is shown to be effective in improving new curricula, professional training of teachers on new curricula, and teaching methods, not sufficient in this regard. The final results from this research showed that there is an urgent need to think about ways of improving integrated plan between the Ministry of Education and universities to ensure a high level of teachers for the primary education. It is also important to rethink about scientific literacy.

Depending on the results from this study, the researcher strongly believed that the educational efforts must be focused on the following issues to enhance the primary science education: -Achieving professionalism in primary science education through applying the following:

- Standards of professional teachers.

- Code of ethics for the teaching science profession.

- Developing a new model for educational supervision especially "science supervision"

- Designing effective teacher training programs to enable them to acquire the necessary proficiencies and skills for an effective science teaching. There is a dire need at present to establish a special center concerned with training science teachers to raise their scientific literacy.

- Attaching greater attention to the student's mastery of the required competencies and skills in science.

- Conducting a comprehensive review of the modern curricula and textbooks to assess their quality for the upcoming phase, especially that current Arab Spring entails promoting students' critical thinking, problem solving skills, creativity and scientific practical approach.

Thus results of the study revealed a gap between actual and desired level. This necessitates taking majority of the teachers, supervisors to improve teaching, placing more emphasis on parents' contribution to the teaching- learning process and spreading awareness on the importance of unifying efforts of all concerned parties to improve outcomes of the educational process, especially in science teaching spheres. 


\section{References}

[1] Abell, S. K., \& Roth, M., (1992). Constraints to teaching elementary science: A case study of a science enthusiast student. Science Education, 76, 581-595.

[2]Ahmet B., \& Murat. G., (2009). Investigating level of the scientific literacy of primary school teacher candidates. Asia-Pacific Forum on Science Learning and Teaching, Volume 10, Issue 1.

[3] Alshiek, O., (1999). Jordanian schools towards 21century.A bed hameed Showman company. Amman. Department of Employment, Education, and Training.

[4] Anthony, P., (2003),Developing Attitudes to Science Education Scales for Use with Primary Teachers. International Journal of Science Education, 25, 23.

[5] Appleton, K., (2003). How Do Beginning Primary School Teachers Cope with Science? Toward an Understanding of Science Teaching Practice. Research in Science Education, 33, 1-25.

[6] Chin, Chi-Chin, (2005). First-Year Pre-Service Teachers in Taiwan--Do They Enter the Teacher Program with Satisfactory Scientific Literacy and Attitudes Toward Science?. International Journal of Science Education, 27 $1549-1570$

[7] Crovrther, D., \& Bonnster, R., (1997), Science Experiences \& Attitudes of Elementary Education Majors as they Experience an Alternative content Biology Course: A Multiple Case Study \& Substantive theory, University of Nevada -Reno. University of Nebraska - Lincoln. http://www.eric.ed.gov/PDFS/ED406149 .pdf (access date: 10 November 2011)

[8] [DEET], (1989). Discipline review of teacher education in mathematics and science. Canberra, Australia: Australian Government Publishing Service.

[9] Eick, C.J., \& Reed, C, J., (2002). What Makes InquiryOriented Science Teacher? The Influences of Learning Histories on Student Teacher Role Identify and practice. Science Teacher Education, 86,401-416.

[10] Fan, X. T., \& Chen, M., (2001). Parental involvement and students' academic achievement: A meta-analysis. Educational Psychology Review, 13, 1-22.

[11] Lena, N., (2005). Status of teaching science. Dissertation abstract. Amman Arab University.

[12] Mellado, V., Blanco, L. J., \& Ruiz, C. (1998). A framework for learning to teach science in initial primary teacher education. Journal of Science Teacher Education, 9, 195-219.

[13] Ministry of Education. (1989-1999). File of plan for developing education in Jordan. Amman- Jordan.

[14] Smith, D. C., \& Neale, D. C., (1991). The construction of subject matter knowledge in primary science teaching. Advances in Research on Teaching, 2, 187-243.

[15] Stefanich, G. P., \& Kelsely, K.W., (1989). Improving science attitudes of presrvice teachers. Science Education, 73, 187-194.

[16] Symington, D., (1980). Elementary school teachers' knowledge of science and its effect on choice between alternative verbal behaviours. Research in Science Education, 10, 69-76.

[17] Symington, D., Hayes, D., (1989). What do you need to know to teach science in the primary school? Research in Science Education, 79(1), 278-285.

[18] Tsai, C. (2002). Nested epistemologies: science teachers' beliefs of teaching, learning and science. International Journal of Science Education, 24(8), 771783.

[19] UNESCO, (2003), Learning for all, Abstract of Gender and education. Organization of the United Nations Educational, Scientific and Cultural Organization. Beirut.

[20] Yates, S., \& Goodrum, D., (1990). How confident are primary school teachers in teaching science? Research in Science Education, 20, 300-305.

[21] Ziadan, M., Factors sufficiently productive in Education. Sunrise House press. Jeddah. 